$1-1-1995$

\title{
Canopy arthropods at Fernow Experimental Forest in West Virginia's Allegheny Mountain section: III : families of arthropods on foliage and under burlap bands
}

Linda Butler

Gregory A. Chrislip

Vicki Kondo

Follow this and additional works at: https://researchrepository.wvu.edu/ wv_agricultural_and_forestry_experiment_station_bulletins

\section{Digital Commons Citation}

Butler, Linda; Chrislip, Gregory A.; and Kondo, Vicki, "Canopy arthropods at Fernow Experimental Forest in West Virginia's Allegheny Mountain section: III : families of arthropods on foliage and under burlap bands" (1995). West Virginia Agricultural and Forestry Experiment Station Bulletins. 714.

https://researchrepository.wvu.edu/wv_agricultural_and_forestry_experiment_station_bulletins/605 
Canopy Arthropods at Fernow Experimental Forest in West Virginia's Allegheny Mountain Section: III. Families of Arthropods on Foliage and Under Burlap Bands

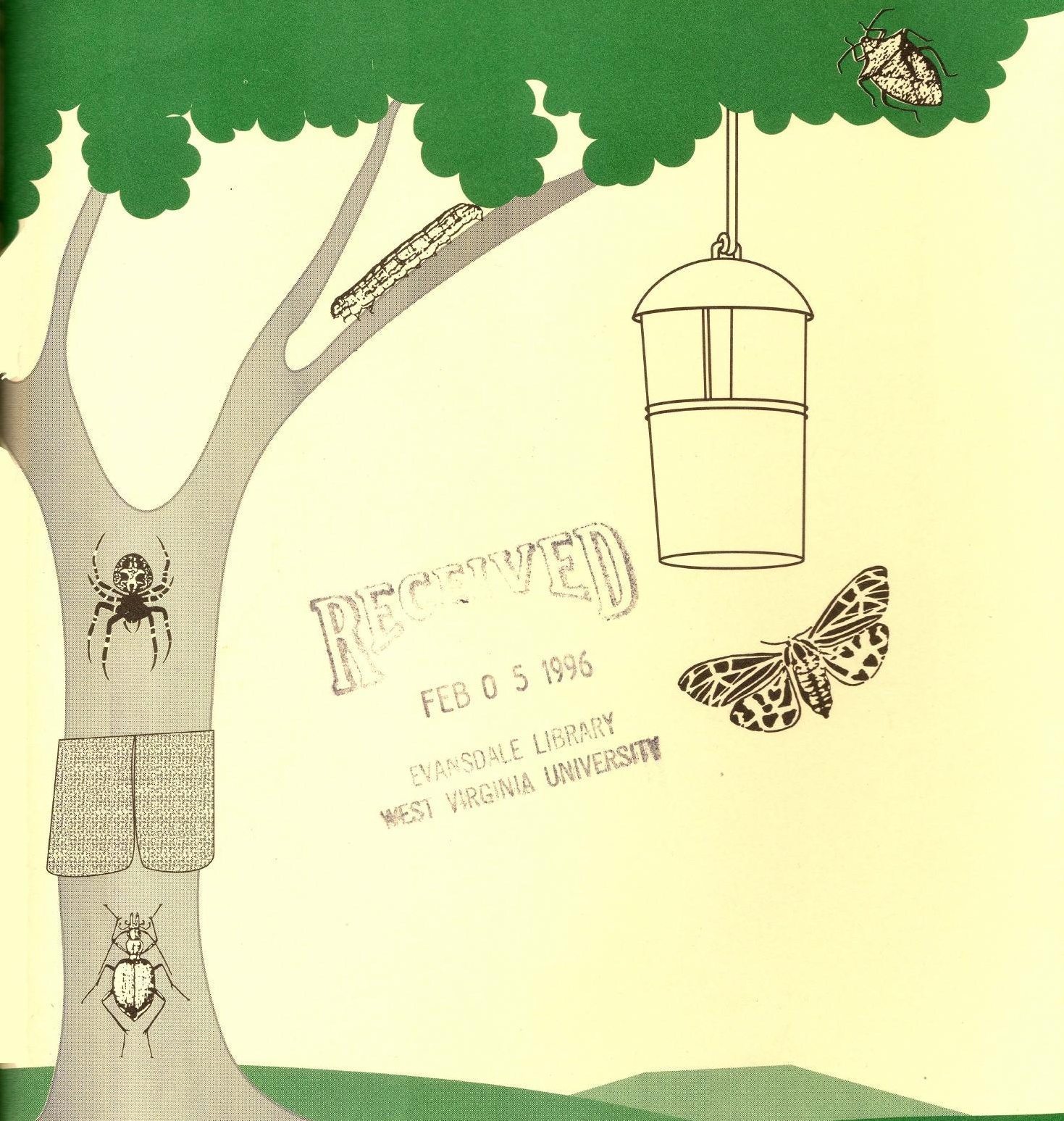

Bulletin 714 • December 1995 Agricultural and Forestry Experiment Station West Virginia University 


\section{Authors}

Linda Butler is Professor of Entomology and Gregory Chrislip and Vicki Kondo are Entomology Research Assistants, Division of Plant and Soil Sciences, College of Agriculture and Forestry, West Virginia University.

This research was supported by a grant from the USDA Forest Service. We would like to acknowledge the assistance and cooperation of the USDA Forest Service Appalachian Integrated Pest Management Program personnel, our undergraduate field and laboratory assistants and the data management assistance of Dr. Edwin Townsend.

West Virginia University

Agricultural and Forestry Experiment Station

College of Agriculture and Forestry

Rosemary Haggett, Director

Morgantown, WV 


\title{
Canopy Arthropods at Fernow Experimental Forest in West Virginia's Allegheny Mountain Section: III. Families of Arthropods on Foliage and Under Burlap Bands
}

\author{
Linda Butler, Gregory Chrislip and Vicki Kondo
}

\section{INTRODUCTION}

We began studying canopy arthropods in deciduous forests of West Virginia in 1984. Since that time our emphasis has been placed entirely or in large part on Macrolepidoptera in blacklight traps, on hardwood foliage, or under burlap/ canvas bands (Butler 1992; Butler and Kondo 1991, 1993; Butler et al. 1995 a, b, c). The studies have been conducted for two purposes: (1) to collect baseline data prior to gypsy moth defoliation and subsequent application of insecticides, and (2) to evaluate the impact of gypsy moth suppression methods.

In 1989 we began a study to evaluate non-target impact of the insect growth regulator Dimilin (diflubenzuron) (1-4 chlorophenyl)-3-(2, 6-diflubenzoyl) urea) on canopy arthropods. Dimilin has been applied to hundreds of thousands of acres in the United States for suppression of gypsy moth, Lymantria dispar (L.) (Lepidoptera: Lymantriidae). From 1989 through 1994 we sampled arthropods in the forest canopy and under burlap bands in four closed watersheds on the Fernow Experimental Forest near Parsons in the Allegheny Mountain section of West Virginia. In 1992 Dimilin was applied to two of the watersheds. Elsewhere we present results of impact of the Dimilin on canopy arthropods, evaluation of macrolepidopterous moths sampled by blacklight trap, and richness and abundance of macrolepidopterous larvae on foliage and under bands. Here we present richness and abundance of arthropod families taken from foliage and collected during the six-year study period from burlap bands of mixed birch (Betula spp.), black cherry (Prunus serotina Ehrh.), mixed maples (Acer spp.) and mixed oaks (Quercus spp.). Used in this context, richness refers to number of families, abundance refers to total numbers of individuals. 


\section{MATERIALS AND METHODS}

\section{Study Sites}

The Fernow Experimental Forest encompasses 1,902 ha and has been divided into a series of watersheds for research purposes. This study was conducted on watersheds 1, 4, 7, and 13. Prior to establishment of the Fernow Experimental Forest in 1934, the land was heavily cut between 1905 and 1910. Additional timbering occurred on several of the four watersheds from the early 1950s through the late 1970s. At the Fernow, common tree species on the better sites include yellow-poplar (Liriodendron tulipifera L.), sugar maple (Acer saccharum Marsh.), black cherry, white ash (Fraxinus americana L.), American basswood (Tilia americana L.) and red oak (Quercus rubra L.). Dominant tree species on the poorer sites include various species of oak (Quercus spp.), hickory (Carya spp.), sourwood (Oxydendrum arboreum (L.) DC) and sassafras (Sassafras albidum (Nutt.) Nees) (Adams et al. 1993).

Importance values (IV) for tree species on watersheds 1, 4, 7, and 13 were determined by Stephenson 1992 (unpublished) in which he evaluated species on five small plots $\left(100 \mathrm{~m}^{2}\right)$ within each watershed, well away from watershed boundaries. All plots with stems greater than $2.5 \mathrm{~cm}$ DBH (diameter breast height) were considered to be trees. Individual tree species were given an importance value by adding the relative basal area plus relative density and dividing by two. Stephenson's importance values are used to characterize vegetation on the four watersheds that comprised this study.

Watershed 1 is 30.11 ha with a NE aspect. It has not been timbered since 1958. Tree species with the highest importance values are sugar maple, American basswood, beech (Fagus grandifolia Ehrh.), black locust (Robinia pseudoacacia L.), cucumber magnolia (Magnolia acuminata L.) and red oak. Importance values for the four species groups sampled in this study were 29.2 for sugar maple, 2.6 and 1.5 for yellow birch (Betula lutea Michx. f.) and black birch (Betula lenta L.), respectively, and 3.7 for red oak. Red maple (Acer rubrum L.) and black cherry were sparse on watershed 1 .

Watershed 4 is 38.73 ha with an ESE aspect. The most abundant tree species with respect to importance values are beech, sugar maple, striped maple (Acer pensylvanicum L.), yellow-poplar, American basswood and red oak. Importance values for trees sampled in this study were 16.6 and 2.4 for sugar maple and red maple, respectively, 1.0 for black birch and 7.4 for red oak. Black cherry was represented on watershed 4 by a few large trees and abundant young trees in the understory, but the young trees were too small to have been counted in Stephenson's importance values. Watershed 4 is a relatively mature forest, not having been timbered since 1910 .

Watershed 7 is 24.23 ha with an $\mathrm{E}$ aspect. It is the youngest of the forest stands, having been last cut and treated with herbicides in 1969. The most abun- 
dant species (IV) are black birch, sugar maple, red oak, and yellow-poplar. Importance values of trees sampled in this study were 15.4 for sugar maple, 9.2 for red oak, 33.3 for black birch and 8.4 for black cherry.

Watershed 13 is 14.23 ha with a NNE aspect. Light-selective timbering of this watershed occurred until 1960, but it is a relatively mature stand. Predominant species (IV) are sugar maple, red oak, yellow-poplar, black cherry and black birch. Importance values for species used in this study were 30.5 for sugar maple, 1.1 for red maple, 29.3 for red oak, 6.4 for black birch and 6.6 for black cherry.

\section{Sampling Methods}

We began sampling arthropods on all four watersheds in 1989 by means of burlap banding of trees and pole pruning of foliage.

Burlap bands $24 \mathrm{~cm}$ wide were stapled at breast height to trees. Ten trees each of black birch and black cherry were banded in late April 1989 on all four watersheds. Ten mixed maples were added on each watershed on 5 July 1989. Ten mixed oaks per watershed were added early May 1990 giving a total of 160 banded trees for the study. Each year bands were installed in late April and sampling was begun early to mid-May: 4 May 1989; 14 May 1990; 6 May 1991; 11 May 1992; 10 May 1993; and 9 May 1994. Bands were left in place until mid-August each year and then removed after the last sampling date: 15 August 1989; 13 August 1990; 12 August 1991; 10 August 1992; 9 August 1993; and 8 August 1994. Each week all bands were checked and all arthropods removed and returned to the laboratory for identification to family. Burlap bands mimic naturally occurring bark flaps serve as resting sites for arthropods that move up and down the trunks.

The first foliage samples were taken 17 May 1989 and consisted of two 25branch tip samples of mixed birch (black and yellow) and two of black cherry on each of the four watersheds providing a total of 16 samples per sampling date. On 27 June 1989 a similar sampling procedure was added for mixed maple (sugar and red) for a total of 24 samples taken for the remainder of the season. Sampling of mixed oak (primarily red oak) was added at the beginning of the 1990 sampling season for a total of 32 samples of foliage on each sampling date.

Foliage sampling was begun soon after leaf expansion each spring: 17 May 1989; 15 May 1990; 7 May 1991; 12 May 1992; 11 May 1993; and 8 May 1994 and was continued until Mid-August each year. During the six years of the study, foliage samples were taken each week for a total of 15 sampling dates each season. Foliage was collected from low- to mid-canopy with pole pruners equipped with large plastic catch bags to collect the foliage that fell. The 32 foliage samples collected from mixed birch, black cherry, mixed maple and mixed oak were returned to the laboratory where all arthropods were removed and identified to family. 
After arthropods were removed, all leaves from the twigs in each sample were placed in paper bags, oven dried, and weighed. The average dry weight of one foliage sample, regardless of foliage species, was about 50 grams.

On 16 May 1992, Dimilin 4L was applied to watersheds 1 and 13 at a rate of 0.5 oz. AI/acre. Elsewhere we will discuss the impact of that treatment on canopy arthropods. Here we present overall richness and abundance of arthropods during the six-year study on the Fernow and present information on seasonal range and host associations. Voucher specimens from the study are deposited in the WVU Arthropod Collection.

\section{RESULTS}

From 1989 to 1994, arthropod family richness was 225 on foliage and 188 under bands of black birch, black cherry, mixed maples and mixed oaks (Table 1). Under bands, Phalangida was by far the most abundant taxon with more than 17,000 individuals being recorded (Table 2). Other taxa that were represented by more than 1,000 individuals during the study were Lymantriidae, Carabidae, Formicidae, Gryllacrididae, Agelenidae, Noctuidae, Diplopoda and Miridae. An additional 22 taxa were recorded in numbers exceeding 100, while for 74 taxa, numbers were five or less for the six-year study.

Taxa under burlap bands include those that typically move up from the forest-floor litter layer seeking shelter (Phalangida, Gryllacrididae, Diplopoda); those that move from the tree canopy downward seeking temporary shelter (Lymantriidae, Noctuidae), predators and omnivores that seek food on tree trunks (Carabidae, Formicidae, Agelenidae); and many "tourists" that were recorded in low numbers and opportunistically shelter under burlap.

Most taxa appear to show no affinity for bands on a particular tree species. Where notably greater numbers of individuals occur on a tree species, it is related to feeding preference of Lepidoptera: Lymantria dispar, Lymantriidae, preferring oak foliage; Malacosoma americanum (F.), Lasiocampidae, preferring black cherry. Some preference may also be shown for texture of tree bark.

Similar abundance of arthropods was noted for each of the four tree species groups. The mixed oaks had the highest abundance from burlap bands at 14,781 despite having not been sampled at all in 1989, the initial year of the study.

The most abundant foliage arthropods were the juice feeders Aphididae (with more than 27,000 individuals), Cicadellidae (with almost 11,000) and Miridae (with almost 10,000) (Table 3). Other families (or superfamilies) represented by more than 1,000 individuals include the thrips (Phlaeothripidae); the caterpillars of Geometridae, Noctuidae and Gelechiidae; the beetles (Curculionidae, Chrysomelidae, and Elateridae); the bark lice (Psocidae and Polypsocidae); the spiders (Theridiidae, Araneidae and Dictynidae); the plant-juice feeders (Membracidae, Eriosomatidae, Pentatomidae and Cercopidae); the flies (Sciaridae and Cecidomyiidae), and the Hymenoptera (Formicidae and Chalcidoidea). 
An additional 51 taxa were represented by 100 or more individuals while 58 taxa were recorded as five or fewer individuals.

The mixed birch trees had the greatest abundance of arthropods at 51,771, followed by black cherry at 25,690, mixed maples at 22,420 and mixed oaks at 15,670. Particularly noteworthy was the abundance of Aphididae $(19,951)$ and Cicadellidae $(6,867)$ on birch, numbers that greatly exceeded any other taxon on any host tree species. Some other taxa with much higher numbers on one tree species group included Geometridae on black cherry, Membracidae on oak, Eriosomatidae on birch and Cercopidae on birch. Similar distribution of arthropod numbers among tree groups was seen for Phlaeothripidae, Theridiidae, Formicidae, Araneidae and Gelechiidae, among others. It must be noted again that sampling intensity was lower on oaks and maples than on birches and black cherry since a full sampling season with all four tree species groups was not begun until 1990.

Included on foliage in the forest canopy are the juice-feeding herbivores, chewing herbivores, predators, parasitoids, epiphytes (lichen and pollen feeders) and tourists, individuals that are "passing through."

\section{DISCUSSION}

The Fernow study has shown that the niches provided by trunks and canopies of hardwood trees are occupied by abundant and diverse arthropods. While high diversity is indicated by the 188 taxa under bands and 225 taxa on foliage, a much smaller number of taxa were relatively abundant in the two habitats.

Little difference was noted among tree species groups in richness and abundance of arthropods under bands. Since burlap bands mimic naturally occurring bark flaps, most of the arthropods occurring under burlap appear to be opportunistically seeking temporary shelter regardless of tree species.

Carabidae (ground beetles) is a large family of primarily predatory beetles that generally hide during the day under stones, logs, bark or debris and feed at night (Borror et al. 1989). These beetles were abundant under bands of all tree species groups.

The ants, Formicidae, are social insects that are found in great abundance in forests. Ants may nest in the soil, dead wood or living plant parts and may act as predators, scavengers or feed on seeds, sap, nectar or honeydew from juicefeeding insects (Borror et al. 1989). Ants use tree trunks as nesting sites and highways for food searching. It is interesting to note that more ants were taken from bands of oaks while more honeydew-producing sap-feeders on foliage were found on birch.

Gryllacrididae are cave and camel crickets that feed on decaying vegetation and fungi and are common in cracks and crevices, decaying logs and hollow trees (Blatchley 1920). Burlap bands apparently provide preferred sheltering sites for these arthropods. 
Eighteen families of spiders were taken under bands. Spiders are predators of other arthropods and catch their prey by means of webs, foraging for and pouncing on prey or lying in wait for their prey (Borror et al. 1989). The Agelenidae or funnel-web spiders were the most abundant spiders under bands and were frequently taken from small webs.

The second most abundant Lepidoptera larvae under bands were the Noctuidae, particularly the species Polia latex (Gn.), Orthosia rubescens (Wlk.), Abagrotis alternata (Grt.) and Lithophane hemina Grt. (Butler et al. 1995c). Abagrotis alternata moves from understory vegetation, particularly Vaccinium where it feeds, to shelter under bands. The other common noctuids use the foliage of the respective host trees under which bands they sheltered.

The millipedes (Diplopoda) are typically found in damp locations, under ground litter, in moss, soil or decayed wood (Borror et al. 1989). They are commonly found in bark crevices on tree trunks and readily shelter under burlap bands.

Most mirid plant bugs are plant-juice feeders but some species are predators on other arthropods or are associated with fungi on tree trunks (Slater and Baranowski 1978). These are the mirid species most commonly taken under bands at Fernow.

Many of the less abundant arthropod taxa recorded in this study under burlap bands (Table 2) show life styles similar to those discussed: scavengers, predators or herbivores coming up from the litter layer; herbivores coming down from the canopy, or predators or lichen feeders foraging for food on tree trunks. Many of the taxa recorded under bands are likely to be opportunistically using bands for temporary shelter, including such beetles as Elateridae, Curculionidae, Cerambycidae and Scarabaeidae, flies such as Tipulidae, Anthomyiidae and Empididae, short-horned grasshoppers (Acrididae) and adult forms whose larvae are aquatic, such as nemourid and leuctrid stoneflies.

The most abundant family of foliage arthropods was Aphididae with 27,350 individuals over the six-year study. Seventy-three percent of the aphids were collected on birch. The Cicadellidae, the second most abundant family, were also most numerous on birch, representing 63 percent of the total leafhopper catches. Miridae, also a family of plant-juice feeders, was the third-ranked family on foliage and was recorded in greatest abundance on birch and maple. Thrips of the family Phlaeothripidae were the fourth most abundant. Members of this family are primarily predaceous on other arthropods (Borror et al. 1989).

Chewing herbivores were well represented among the most abundant families on foliage. Geometrid larvae were in highest numbers, with 5,688 being recorded during the study. Fifty-seven percent of these were taken from black cherry and were primarily Lomographa spp. (Butler et al. 1995c). Other abundant mandibulate herbivores included the weevils (Curculionidae), leaf beetles (Chrysomelidae) and caterpillars of the families Noctuidae and Gelechiidae. Two 
families of Psocoptera (Psocidae and Polypsocidae) were abundant on the foliage; these insects feed primarily on lichens, pollen and algae (Borror et al. 1989).

The spiders of the families Theridiidae, Araneidae and Dictynidae were relatively abundant on foliage. Members of all three of these families construct webs with which they capture prey (Borror et al. 1989).

Additional juice-feeding insects that were recorded at 1,000 or above include the Membracidae (treehoppers), Eriosomatidae (woolly and gall aphids), Pentatomidae (stink bugs) and Cercopidae (spittlebugs). Some pentatomids on foliage are predaceous, not herbivorous.

Among the Diptera, the most abundant were the Sciaridae (fungus gnats) whose adults rest in the canopy but whose larvae live primarily in fungi. The Cecidomyiidae (Diptera) gall midges were also relatively abundant as were the Chalcidoidea (Hymenoptera), whose members are primarily parasitic on other insects. Lastly, among the taxa recorded in numbers greater than 1,000 were the Elateridae, whose larvae feed on plant roots or in decayed wood while adults are herbivores.

From 1990 to 1992, Butler et al. (1995a) evaluated arthropod richness and abundance in canopies of mixed oaks in West Virginia's Eastern Ridge and Valley section. Methods similar to those in the current study were used. On oak, during the three-year period, we recorded 200 taxa of arthropods. The most abundant taxa were Aphididae, Lymantriidae, Curculionidae, Tenthredinidae, Pergidae, Coccidae, Cicadellidae, Noctuidae, Reduviidae and Miridae. The study sites were predominantly oak, while the Fernow watersheds were much more diverse in tree composition. This may account for the overall high arthropod diversity in the Fernow trees during the current study. We note however, that diversity in oak canopies was higher in the Butler et al. (1995a) study than in the Fernow study. Gypsy moth populations were increasing in the Eastern Ridge and Valley section during the earlier study, accounting for the high abundance in the Lymantriidae. The sawflies (Tenthredinidae and Pergidae) were particularly abundant on oaks in the earlier study but in moderate to low numbers at Fernow. Otherwise, many similarities exist between the two studies in overall composition of arthropods.

Pachamuthu and Butler (submitted manuscript) evaluated richness and abundance in canopies of chestnut oak at Coopers Rock State Forest in 1992 and 1993 and found Membracidae, Aphididae, Lymantriidae, Miridae, Gryllidae, Geometridae, and Gelechiidae to be most abundant.

Canopy arthropods constitute one of the richest and least studied faunas on earth (Blanton 1990). Numerous researchers have recommended the need for more information on composition, trophic structures and species diversity of canopy arthropods (Hijii 1983; Schowalter and Crossley 1983). 


\section{SUMMARY}

Arthropods were collected weekly from burlap bands and foliage of birch, black cherry, maple and oak May-August 1989-1994. Taxon (primarily family) richness was 188 for bands and 225 for foliage. Total arthropod abundance was 115,551 on foliage and 47,788 under bands. The most abundant arthropods under bands were Phalangida > Lymantriidae $>$ Carabidae $>$ Formicidae $>$ Gryllacrididae. Arthropods most abundant on foliage were Aphididae > Cicadellidae $>$ Miridae $>$ Phlaeothripidae $>$ Geometridae. Canopy and tree trunk arthropods are diverse and numerous on the Fernow Experimental Forest.

\section{LITERATURE CITED}

Adams, M.B., J.W. Kochenderfer, F. Wood, T.R. Angradi, and P. Edwards. 1993. Forty years of hydrometerological data from the Fernow Experimental Forest, West Virginia. USDA Forest Service. Gen. Tech. Rpt. NE-104. 24 pp.

Blanton, C.M. 1990. Canopy arthropod sampling: A comparison of collapsible bag and fogging methods. J. Agric. Entomol. 7:41-51.

Blatchley, W.S. 1920. Orthoptera of Northeastern America with Especial Reference to the Faunas of Indiana and Florida. The Nature Publishing Company, Indianapolis. $784 \mathrm{pp}$.

Borror, D.J., C.A. Triplehorn, and N.F. Johnson. 1989. An Introduction to the Study of Insects. 6th ed. Saunders College Publishing, Philadelphia. 875 pp.

Butler, L. 1992. The community of macrolepidopterous larvae at Coopers Rock State Forest, West Virginia: a baseline study. Can. Entomol. 124:1149-1156.

Butler, L. and V. Kondo. 1991. Macrolepidopterous moths collected by blacklight trap at Coopers Rock State Forest, West Virginia: a baseline study. WV Agric. and For. Exp. Sta. Bull. 705. 25 pp.

Butler, L. and V. Kondo. 1993. Impact of Dimilin on non-target Lepidoptera: Results of an operational gypsy moth suppression program at Coopers Rock State Forest, West Virginia. WV Agric. and For. Exp. St. Bull. 710. 21 pp.

Butler, L., V. Kondo, and G. Chrislip. 1995b. Canopy arthropods at Fernow Experimental Forest in West Virginia's Allegheny Mountain Section: I. Macrolepidopterous moths collected by blacklight trap during a Dimilin impact study. WV Agric. and For. Exp. Sta. Bull. 712. 17 pp.

Butler, L., G. Chrislip, and V. Kondo. 1995c. Canopy arthropods at Fernow Experimental Forest in West Virginia's Allegheny Mountain Section: II. Macro- 
lepidopterous larvae on foliage and under burlap bands. WV Agric. and For. Exp. Sta. Bull. 713. 16 pp.

Butler, L., C. Zivkovich, and B.E. Sample. 1995a. Richness and abundance of arthropods in the oak canopy of West Virginia's Eastern Ridge and Valley Section during a study of impact of Bacillus thuringiensis with emphasis on macrolepidoptera larvae. WV Agric. and For. Exp. Sta. Bull. 711.

Hijii, N. 1983. Arboreal arthropod fauna in a forest: 1. Preliminary observation on seasonal fluctuation in density, biomass and faunal composition in a Chamaecyparis obtusa plantation. Jap. J. Ecol. 33:435-444.

Pachamuthu, P. and L. Butler. Richness and abundance of canopy arthropods in different strata of chestnut oak at Coopers Rock State Forest, West Virginia. Canad. Entomol. (submitted)

Schowalter, T.D. and D.A. Crossley, Jr. 1983. Forest arthropods as sodium, potassium, magnesium and calcium pools in forests. Forest Ecol. and Mgmt. 7:143148.

Slater, J.A. and R.M. Baranowski. 1978. How to Know the True Bugs. Wm. C. Brown Co., Dubuque, Iowa. 256 pp.

TABLE 1.

Richness ${ }^{1}$ and abundance of arthropods on foliage and under bands of mixed birch, black cherry, mixed maples and mixed oaks at Fernow Experimental Forest, West Virginia, 1989-1994².

\begin{tabular}{lrrrrr}
\hline & \multicolumn{5}{c}{ Tree Species } \\
\cline { 2 - 6 } & Mixed & Black & Mixed & Mixed & \\
& Birch & Cherry & Maple & Oak & \multicolumn{1}{c}{ Total } \\
\hline Foliage Richness & 163 & 170 & 160 & 171 & 225 \\
Foliage Abundance & 51,771 & 25,690 & 22,420 & 15,670 & 115,551 \\
Band Richness & 136 & 136 & 133 & 129 & 188 \\
Band Abundance & 10,435 & 10,864 & 11,708 & 14,781 & 47,788 \\
\hline
\end{tabular}

${ }^{1}$ Richness refers to number of taxa collected during the study; the taxon categories expressed in this paper are primarily arthropod families.

${ }^{2}$ Mixed oaks were not sampled in 1989. 
TABLE 2.

Abundance of arthropods listed by taxa (primarily families) collected from burlap bands of black birch, black cherry, mixed maple and mixed oak at Fernow Experimental Forest, 1989-1994. Taxa are arranged from most to least abundant.

\begin{tabular}{|c|c|c|c|c|c|}
\hline \multirow[b]{2}{*}{ Family } & \multicolumn{5}{|c|}{ Tree Species Groups } \\
\hline & $\begin{array}{l}\text { Black } \\
\text { Birch }\end{array}$ & $\begin{array}{l}\text { Black } \\
\text { Cherry }\end{array}$ & $\begin{array}{l}\text { Mixed } \\
\text { Maple }\end{array}$ & $\begin{array}{c}\text { Mixed } \\
\text { Oak }\end{array}$ & Total \\
\hline Phalangida & 3450 & 4289 & 4334 & 5134 & 17002 \\
\hline Lymantriidae & 788 & 583 & 891 & 2308 & 4570 \\
\hline Carabidae & 1195 & 749 & 1024 & 962 & 3930 \\
\hline Formicidae & 827 & 464 & 866 & 1209 & 3366 \\
\hline Gryllacrididae & 708 & 770 & 788 & 1036 & 3302 \\
\hline Agelenidae & 574 & 790 & 859 & 867 & 3090 \\
\hline Noctuidae & 470 & 973 & 425 & 497 & 2365 \\
\hline Diplopoda & 186 & 262 & 332 & 395 & 1175 \\
\hline Miridae & 224 & 180 & 361 & 369 & 1134 \\
\hline Entomobryidae & 423 & 137 & 182 & 168 & 910 \\
\hline Theridiidae & 162 & 168 & 196 & 131 & 657 \\
\hline Geometridae & 63 & 91 & 78 & 129 & 361 \\
\hline Chilopoda & 113 & 48 & 102 & 85 & 348 \\
\hline Clubionidae & 62 & 58 & 84 & 106 & 310 \\
\hline Elateridae & 71 & 41 & 72 & 87 & 271 \\
\hline Tenebrionidae & 30 & 59 & 64 & 108 & 261 \\
\hline Pentatomidae & 39 & 96 & 67 & 57 & 259 \\
\hline Salticidae & 65 & 50 & 63 & 75 & 253 \\
\hline Lasiocampidae & 34 & 120 & 46 & 52 & 252 \\
\hline Tortricidae & 57 & 53 & 57 & 51 & 218 \\
\hline Tipulidae & 52 & 54 & 48 & 55 & 209 \\
\hline Tenthredinidae & 31 & 31 & 31 & 86 & 179 \\
\hline Reduviidae & 20 & 56 & 48 & 43 & 167 \\
\hline Gryllidae & 25 & 41 & 45 & 52 & 163 \\
\hline Membracidae & 38 & 15 & 39 & 70 & 162 \\
\hline Coccinellidae & 65 & 28 & 19 & 45 & 157 \\
\hline Chrysomelidae & 36 & 59 & 33 & 23 & 151 \\
\hline Psocidae & 82 & 8 & 40 & 5 & 135 \\
\hline Curculionidae & 30 & 18 & 26 & 58 & 132 \\
\hline Cerambycidae & 24 & 27 & 27 & 24 & 102 \\
\hline Arctiidae & 17 & 37 & 19 & 28 & 101 \\
\hline Araneidae & 27 & 23 & 32 & 7 & 89 \\
\hline Gelechiidae & 14 & 25 & 14 & 33 & 86 \\
\hline Machilidae & 20 & 16 & 18 & 23 & 77 \\
\hline Acrididae & 17 & 25 & 21 & 13 & 76 \\
\hline Cantharidae & 15 & 15 & 12 & 15 & 57 \\
\hline Anthomyiidae & 18 & 7 & 9 & 22 & 56 \\
\hline Philodromidae & 11 & 11 & 14 & 13 & 49 \\
\hline Chalcidoidea & 3 & 41 & 1 & 3 & $\begin{array}{c}48 \\
\text { ntinued }\end{array}$ \\
\hline
\end{tabular}




\begin{tabular}{|c|c|c|c|c|c|}
\hline \multirow[b]{2}{*}{ Family } & \multicolumn{5}{|c|}{ Tree Species Groups } \\
\hline & $\begin{array}{l}\text { Black } \\
\text { Birch }\end{array}$ & $\begin{array}{c}\text { Black } \\
\text { Cherry }\end{array}$ & $\begin{array}{l}\text { Mixed } \\
\text { Maple }\end{array}$ & $\begin{array}{c}\text { Mixed } \\
\text { Oak }\end{array}$ & Total \\
\hline Ichneumonidae & 11 & 13 & 13 & 10 & 47 \\
\hline Coreidae & 8 & 25 & 7 & 7 & 47 \\
\hline Thomisidae & 9 & 13 & 9 & 13 & 44 \\
\hline Lampyridae & 11 & 13 & 12 & 7 & 43 \\
\hline Nitidulidae & 0 & 6 & 2 & 27 & 35 \\
\hline Empididae & 7 & 12 & 9 & 7 & 35 \\
\hline Lygaeidae & 8 & 13 & 9 & 5 & 35 \\
\hline Anyphaenidae & 11 & 8 & 7 & 7 & 33 \\
\hline Scarabaeidae & 5 & 6 & 10 & 11 & 32 \\
\hline Rhagionidae & 4 & 4 & 20 & 4 & 32 \\
\hline Nemouridae & 14 & 14 & 4 & 0 & 32 \\
\hline Lagriidae & 3 & 5 & 10 & 12 & 30 \\
\hline Bibionidae & 7 & 2 & 6 & 14 & 29 \\
\hline Cicadellidae & 9 & 10 & 6 & 1 & 26 \\
\hline Leuctridae & 9 & 11 & 2 & 3 & 25 \\
\hline Melandryidae & 11 & 4 & 3 & 5 & 23 \\
\hline Sminthuridae & 2 & 12 & 0 & 9 & 23 \\
\hline Pyralidae & 7 & 4 & 6 & 4 & 21 \\
\hline Staphylinidae & 9 & 2 & 6 & 3 & 20 \\
\hline Mycetophilidae & 7 & 6 & 4 & 3 & 20 \\
\hline Aphididae & 10 & 4 & 4 & 2 & 20 \\
\hline Tachinidae & 1 & 4 & 5 & 9 & 19 \\
\hline Perlidae & 5 & 10 & 3 & 1 & 19 \\
\hline Halictidae & 3 & 5 & 7 & 3 & 18 \\
\hline Sciaridae & 4 & 5 & 4 & 4 & 17 \\
\hline Oedemeridae & 5 & 1 & 5 & 5 & 16 \\
\hline Pisauridae & 2 & 3 & 5 & 6 & 16 \\
\hline Trombidia & 7 & 2 & 3 & 4 & 16 \\
\hline Chloroperlidae & 4 & 8 & 4 & 0 & 16 \\
\hline Panorpidae & 3 & 5 & 6 & 2 & 16 \\
\hline Buprestidae & 0 & 7 & 4 & 4 & 15 \\
\hline Ostomatidae & 13 & 0 & 0 & 1 & 14 \\
\hline Pedilidae & 8 & 2 & 3 & 1 & 14 \\
\hline Cecidomyiidae & 0 & 0 & 2 & 12 & 14 \\
\hline Braconidae & 0 & 2 & 1 & 11 & 14 \\
\hline Vespidae & 2 & 2 & 6 & 4 & 14 \\
\hline Delphacidae & 5 & 3 & 3 & 3 & 14 \\
\hline Pyrochroidae & 0 & 3 & 8 & 2 & 13 \\
\hline Polypsocidae & 0 & 0 & 13 & 0 & 13 \\
\hline Mordellidae & 4 & 2 & 4 & 2 & 12 \\
\hline Andrenidae & 3 & 1 & 1 & 7 & 12 \\
\hline Linyphiidae & 5 & 1 & 2 & 4 & 12 \\
\hline Erotylidae & 6 & 3 & 1 & 1 & 11 \\
\hline Syrphidae & 3 & 2 & 4 & 2 & 11 \\
\hline Cercopidae & 4 & 3 & 2 & 2 & $\begin{array}{c}11 \\
\text { tinued }\end{array}$ \\
\hline
\end{tabular}




\begin{tabular}{|c|c|c|c|c|c|}
\hline \multirow[b]{2}{*}{ Family } & \multicolumn{5}{|c|}{ Tree Species Groups } \\
\hline & $\begin{array}{l}\text { Black } \\
\text { Birch }\end{array}$ & $\begin{array}{c}\text { Black } \\
\text { Cherry }\end{array}$ & $\begin{array}{l}\text { Mixed } \\
\text { Maple }\end{array}$ & $\begin{array}{c}\text { Mixed } \\
\text { Oak }\end{array}$ & Total \\
\hline Nabidae & 1 & 3 & 3 & 4 & 11 \\
\hline Coccidae & 10 & 0 & 0 & 0 & 10 \\
\hline Notodontidae & 0 & 3 & 2 & 5 & 10 \\
\hline Silphidae & 1 & 0 & 1 & 7 & 9 \\
\hline Cleridae & 0 & 4 & 3 & 2 & 9 \\
\hline Argidae & 2 & 5 & 1 & 1 & 9 \\
\hline Micryphantidae & 3 & 2 & 2 & 2 & 9 \\
\hline Phoridae & 2 & 2 & 0 & 4 & 8 \\
\hline Apidae & 3 & 3 & 1 & 1 & 8 \\
\hline Cimbicidae & 4 & 4 & 0 & 0 & 8 \\
\hline Diprionidae & 4 & 4 & 0 & 0 & 8 \\
\hline Lycosidae & 1 & 1 & 5 & 1 & 8 \\
\hline Oecophoridae & 2 & 2 & 2 & 2 & 8 \\
\hline Lycaenidae & 0 & 1 & 3 & 4 & 8 \\
\hline Plecoptera & 1 & 6 & 0 & 1 & 8 \\
\hline Anobiidae & 2 & 2 & 1 & 2 & 7 \\
\hline Lucanidae & 0 & 1 & 0 & 6 & 7 \\
\hline Chironomidae & 5 & 1 & 0 & 1 & 7 \\
\hline Tettigoniidae & 1 & 2 & 1 & 3 & 7 \\
\hline Athericidae & 0 & 2 & 3 & 1 & 6 \\
\hline Sphecidae & 2 & 3 & 1 & 0 & 6 \\
\hline Dictyopharidae & 1 & 2 & 3 & 0 & 6 \\
\hline Perlodidae & 2 & 4 & 0 & 0 & 6 \\
\hline Mycetophagidae & 2 & 1 & 2 & 0 & 5 \\
\hline Endomychidae & 1 & 2 & 1 & 1 & 5 \\
\hline Dolichopodidae & 1 & 1 & 2 & 1 & 5 \\
\hline Anthophoridae & 1 & 0 & 0 & 4 & 5 \\
\hline Anthocoridae & 1 & 0 & 1 & 3 & 5 \\
\hline Dictynidae & 1 & 1 & 1 & 2 & 5 \\
\hline Sphingidae & 2 & 2 & 0 & 1 & 5 \\
\hline Papilionidae & 1 & 1 & 1 & 2 & 5 \\
\hline Anthicidae & 1 & 1 & 1 & 1 & 4 \\
\hline Muscidae & 1 & 1 & 0 & 2 & 4 \\
\hline Alydidae & 1 & 0 & 2 & 1 & 4 \\
\hline Chrysopidae & 0 & 0 & 3 & 1 & 4 \\
\hline Gnaphosidae & 1 & 0 & 0 & 3 & 4 \\
\hline Lycidae & 1 & 0 & 2 & 0 & 3 \\
\hline Cucujidae & 1 & 0 & 0 & 2 & 3 \\
\hline Psychodidae & 1 & 0 & 2 & 0 & 3 \\
\hline Pompilidae & 0 & 1 & 1 & 1 & 3 \\
\hline Psyllidae & 1 & 1 & 0 & 1 & 3 \\
\hline Gracillariidae & 0 & 0 & 0 & 3 & 3 \\
\hline Heptageniidae & 2 & 1 & 0 & 0 & 3 \\
\hline Alleculidae & 0 & 0 & 1 & 1 & 2 \\
\hline Bostrichidae & 1 & 1 & 0 & 0 & 2 \\
\hline
\end{tabular}




\begin{tabular}{|c|c|c|c|c|c|}
\hline \multirow[b]{2}{*}{ Family } & \multicolumn{5}{|c|}{ Tree Species Groups } \\
\hline & $\begin{array}{l}\text { Black } \\
\text { Birch }\end{array}$ & $\begin{array}{l}\text { Black } \\
\text { Cherry }\end{array}$ & $\begin{array}{l}\text { Mixed } \\
\text { Maple }\end{array}$ & $\begin{array}{c}\text { Mixed } \\
\text { Oak }\end{array}$ & Total \\
\hline Phalacridae & 2 & 0 & 0 & 0 & 2 \\
\hline Brentidae & 1 & 0 & 1 & 0 & 2 \\
\hline Ptilodactylidae & 1 & 0 & 1 & 0 & 2 \\
\hline Lathridiidae & 0 & 1 & 1 & 0 & 2 \\
\hline Lauxaniidae & 1 & 1 & 0 & 0 & 2 \\
\hline Calliphoridae & 0 & 1 & 1 & 0 & 2 \\
\hline Tabanidae & 0 & 0 & 1 & 1 & 2 \\
\hline Lonchopteridae & 0 & 0 & 2 & 0 & 2 \\
\hline Heleomyzidae & 0 & 1 & 0 & 1 & 2 \\
\hline Cynipidae & 0 & 0 & 1 & 1 & 2 \\
\hline Xyelidae & 0 & 2 & 0 & 0 & 2 \\
\hline Xiphydriidae & 1 & 0 & 1 & 0 & 2 \\
\hline Achilidae & 1 & 1 & 0 & 0 & 2 \\
\hline Aradidae & 2 & 0 & 0 & 0 & 2 \\
\hline Hemerobiidae & 1 & 1 & 0 & 0 & 2 \\
\hline Limnephilidae & 1 & 0 & 1 & 0 & 2 \\
\hline Amaurobiidae & 1 & 0 & 1 & 0 & 2 \\
\hline Segestriidae & 1 & 0 & 0 & 1 & 2 \\
\hline Anystidae & 1 & 0 & 0 & 1 & 2 \\
\hline Coleophoridae & 0 & 1 & 0 & 1 & 2 \\
\hline Blattellidae & 0 & 0 & 0 & 2 & 2 \\
\hline Phasmatidae & 0 & 0 & 0 & 2 & 2 \\
\hline Mantidae & 1 & 1 & 0 & 0 & 2 \\
\hline Microcoryphia & 1 & 0 & 0 & 1 & 2 \\
\hline Aeshnidae & 0 & 1 & 1 & 0 & 2 \\
\hline Scolytidae & 0 & 0 & 1 & 0 & 1 \\
\hline Dermestidae & 0 & 1 & 0 & 0 & 1 \\
\hline Anthribidae & 0 & 0 & 1 & 0 & 1 \\
\hline Meloidae & 0 & 1 & 0 & 0 & 1 \\
\hline Bruchidae & 0 & 0 & 0 & 1 & 1 \\
\hline Melyridae & 0 & 0 & 1 & 0 & 1 \\
\hline Cryptophagidae & 0 & 1 & 0 & 0 & 1 \\
\hline Stratiomyidae & 1 & 0 & 0 & 0 & 1 \\
\hline Sarcophagidae & 0 & 0 & 0 & 1 & 1 \\
\hline Chloropidae & 0 & 0 & 1 & 0 & 1 \\
\hline Anthomyzidae & 0 & 0 & 1 & 0 & 1 \\
\hline Proctotrupoidae & 0 & 1 & 0 & 0 & 1 \\
\hline Pamphiliidae & 0 & 1 & 0 & 0 & 1 \\
\hline Siricidae & 0 & 0 & 1 & 0 & 1 \\
\hline Cephidae & 1 & 0 & 0 & 0 & 1 \\
\hline Homoptera & 1 & 0 & 0 & 0 & 1 \\
\hline Cixiidae & 0 & 0 & 1 & 0 & 1 \\
\hline Eriosomatidae & 1 & 0 & 0 & 0 & 1 \\
\hline Rhopalidae & 0 & 0 & 0 & 1 & 1 \\
\hline Tingidae & 0 & 0 & 1 & 0 & 1 \\
\hline
\end{tabular}

continued 


\begin{tabular}{lrcccr}
\hline & \multicolumn{5}{c}{ Tree Species Groups } \\
\cline { 2 - 6 } Family & Black & Black & Mixed & Mixed & \\
\hline Circh & Cherry & Maple & Oak & Total \\
Sialidae & 1 & 0 & 0 & 0 & 1 \\
Phryganeidae & 1 & 0 & 0 & 0 & 1 \\
Hydroptilidae & 0 & 1 & 0 & 0 & 1 \\
Tetragnathidae & 0 & 1 & 0 & 0 & 1 \\
Theridiosomatidae & 0 & 0 & 1 & 0 & 1 \\
Nymphalidae & 0 & 1 & 0 & 0 & 1 \\
Lyonetiidae & 0 & 0 & 0 & 1 & 1 \\
Glyphipterigidae & 0 & 0 & 1 & 0 & 1 \\
Thyatiridae & 1 & 0 & 0 & 0 & 1 \\
Siphlonuridae & 1 & 0 & 0 & 0 & 1 \\
Peltoperlidae & 0 & 1 & 0 & 0 & 1 \\
Libellulidae & 0 & 0 & 1 & 0 & 1 \\
Diplura & 0 & 0 & 1 & 0 & 1 \\
Drepanidae & 0 & 1 & 0 & 0 & 1 \\
\hline TOTALS & 0 & 1 & 0 & 0 & 1 \\
\hline
\end{tabular}

TABLE 3.

Abundance of arthropods listed by taxa (primarily families) collected from foliage of mixed birch, black cherry, mixed maple and mixed oak at Fernow Experimental Forest, 1989-1994. Taxa are arranged from most to least abundant.

\begin{tabular}{lrrrrr}
\hline & \multicolumn{5}{c}{ Tree Species Groups } \\
\cline { 2 - 6 } & Black & Black & Mixed & Mixed & \\
Family & Birch & Cherry & Maple & Oak & Total \\
\hline Aphididae & 19951 & 632 & 3995 & 2772 & 27350 \\
Cicadellidae & 6867 & 1810 & 1534 & 620 & 10830 \\
Miridae & 3304 & 1495 & 3668 & 1196 & 9664 \\
Phlaeothripidae & 1874 & 2420 & 1347 & 683 & 6324 \\
Geometridae & 719 & 3217 & 992 & 760 & 5688 \\
Curculionidae & 1554 & 1371 & 526 & 472 & 3923 \\
Psocidae & 615 & 1297 & 683 & 578 & 3173 \\
Polypsocidae & 770 & 1458 & 651 & 288 & 3167 \\
Theridiidae & 653 & 974 & 893 & 423 & 2943 \\
Membracidae & 189 & 57 & 42 & 2035 & 2323 \\
Eriosomatidae & 1996 & 5 & 14 & 73 & 2087 \\
Sciaridae & 795 & 709 & 454 & 26 & 1984 \\
Formicidae & 738 & 403 & 467 & 365 & 1972 \\
Araneidae & 485 & 478 & 553 & 264 & 1781 \\
& & & & & continued
\end{tabular}




\begin{tabular}{|c|c|c|c|c|c|}
\hline \multirow[b]{2}{*}{ Family } & \multicolumn{5}{|c|}{ Tree Species Groups } \\
\hline & $\begin{array}{l}\text { Black } \\
\text { Birch }\end{array}$ & $\begin{array}{l}\text { Black } \\
\text { Cherry }\end{array}$ & $\begin{array}{l}\text { Mixed } \\
\text { Maple }\end{array}$ & $\begin{array}{c}\text { Mixed } \\
\text { Oak }\end{array}$ & Total \\
\hline Noctuidae & 655 & 428 & 262 & 314 & 1659 \\
\hline Gelechiidae & 343 & 497 & 325 & 489 & 1654 \\
\hline Chrysomelidae & 705 & 421 & 138 & 262 & 1526 \\
\hline Dictynidae & 295 & 521 & 558 & 131 & 1505 \\
\hline Pentatomidae & 570 & 385 & 166 & 130 & 1251 \\
\hline Cercopidae & 814 & 89 & 163 & 52 & 1118 \\
\hline Cecidomyiidae & 549 & 344 & 136 & 62 & 1091 \\
\hline Chalcidoidea & 381 & 265 & 189 & 171 & 1006 \\
\hline Elateridae & 312 & 309 & 258 & 124 & 1003 \\
\hline Philodromidae & 239 & 239 & 290 & 194 & 962 \\
\hline Proctotrupoidea & 422 & 303 & 123 & 53 & 901 \\
\hline Tenthredinidae & 181 & 333 & 19 & 321 & 853 \\
\hline Reduviidae & 376 & 199 & 173 & 98 & 846 \\
\hline Phalangida & 270 & 211 & 206 & 102 & 789 \\
\hline Linyphiidae & 137 & 258 & 213 & 112 & 719 \\
\hline Lyonetiidae & 161 & 267 & 173 & 102 & 704 \\
\hline Tortricidae & 144 & 242 & 112 & 154 & 651 \\
\hline Coccidae & 301 & 165 & 48 & 83 & 597 \\
\hline Cantharidae & 252 & 128 & 117 & 84 & 581 \\
\hline Chironomidae & 251 & 113 & 115 & 55 & 533 \\
\hline Entomobryidae & 181 & 148 & 105 & 59 & 493 \\
\hline Psyllidae & 181 & 54 & 185 & 67 & 487 \\
\hline Lygaeidae & 253 & 151 & 54 & 6 & 464 \\
\hline Salticidae & 142 & 118 & 92 & 95 & 448 \\
\hline Tipulidae & 112 & 156 & 122 & 48 & 439 \\
\hline Coccinellidae & 138 & 118 & 62 & 109 & 427 \\
\hline Braconidae & 110 & 158 & 107 & 51 & 426 \\
\hline Mycetophilidae & 133 & 132 & 111 & 36 & 412 \\
\hline Hemerobiidae & 132 & 100 & 80 & 84 & 396 \\
\hline Gracillariidae & 116 & 182 & 68 & 27 & 393 \\
\hline Thomisidae & 138 & 113 & 93 & 46 & 390 \\
\hline Ichneumonidae & 106 & 90 & 76 & 51 & 323 \\
\hline Syrphidae & 166 & 59 & 46 & 44 & 316 \\
\hline Lymantriidae & 30 & 26 & 57 & 197 & 310 \\
\hline Tingidae & 36 & 188 & 32 & 10 & 266 \\
\hline Empididae & 146 & 45 & 38 & 32 & 262 \\
\hline Anyphaenidae & 72 & 64 & 72 & 45 & 254 \\
\hline Thripidae & 50 & 26 & 132 & 27 & 234 \\
\hline Lasiocampidae & 0 & 169 & 3 & 53 & 225 \\
\hline Coniopterygidae & 24 & 32 & 121 & 44 & 221 \\
\hline Pyralidae & 46 & 56 & 71 & 43 & 216 \\
\hline Notodontidae & 23 & 8 & 88 & 70 & 189 \\
\hline Anystidae & 65 & 59 & 25 & 39 & 187 \\
\hline Staphylinidae & 63 & 57 & 24 & 37 & 180 \\
\hline Phylloxeridae & 12 & 8 & 78 & 74 & $\begin{array}{c}172 \\
\text { ntinued }\end{array}$ \\
\hline
\end{tabular}




\begin{tabular}{|c|c|c|c|c|c|}
\hline \multirow[b]{2}{*}{ Family } & \multicolumn{5}{|c|}{ Tree Species Groups } \\
\hline & $\begin{array}{l}\text { Black } \\
\text { Birch }\end{array}$ & $\begin{array}{l}\text { Black } \\
\text { Cherry }\end{array}$ & $\begin{array}{l}\text { Mixed } \\
\text { Maple }\end{array}$ & $\begin{array}{c}\text { Mixed } \\
\text { Oak }\end{array}$ & Total \\
\hline Lauxaniidae & 61 & 65 & 30 & 10 & 165 \\
\hline Lathridiidae & 42 & 60 & 31 & 29 & 162 \\
\hline Trombidia & 71 & 41 & 31 & 15 & 157 \\
\hline Clubionidae & 34 & 42 & 59 & 16 & 151 \\
\hline Nemouridae & 58 & 25 & 34 & 12 & 128 \\
\hline Arctiidae & 31 & 18 & 16 & 59 & 124 \\
\hline Cynipidae & 45 & 27 & 16 & 31 & 118 \\
\hline Dictyopharidae & 49 & 52 & 12 & 1 & 114 \\
\hline Scarabaeidae & 35 & 5 & 25 & 48 & 113 \\
\hline Chrysopidae & 41 & 42 & 14 & 10 & 107 \\
\hline Micryphantidae & 17 & 44 & 35 & 11 & 107 \\
\hline Sminthuridae & 73 & 12 & 5 & 15 & 105 \\
\hline Tetragnathidae & 45 & 36 & 13 & 11 & 105 \\
\hline Acarina & 75 & 17 & 8 & 2 & 102 \\
\hline Leuctridae & 44 & 17 & 31 & 8 & 100 \\
\hline Gryllidae & 36 & 18 & 16 & 8 & 78 \\
\hline Pselaphidae & 17 & 23 & 11 & 27 & 77 \\
\hline Anthomyiidae & 23 & 37 & 3 & 14 & 76 \\
\hline Bibionidae & 19 & 32 & 17 & 7 & 76 \\
\hline Mordellidae & 17 & 25 & 19 & 10 & 71 \\
\hline Agelenidae & 24 & 12 & 26 & 9 & 70 \\
\hline Cerambycidae & 20 & 27 & 15 & 7 & 68 \\
\hline Drosophilidae & 29 & 13 & 15 & 11 & 68 \\
\hline Simuliidae & 4 & 28 & 22 & 5 & 59 \\
\hline Phalacridae & 15 & 18 & 12 & 12 & 57 \\
\hline Nitidulidae & 12 & 40 & 1 & 2 & 56 \\
\hline Leiodidae & 21 & 23 & 3 & 9 & 56 \\
\hline Ceratopogonidae & 20 & 19 & 14 & 2 & 55 \\
\hline Argidae & 11 & 38 & 0 & 6 & 55 \\
\hline Carabidae & 29 & 11 & 6 & 6 & 51 \\
\hline Nabidae & 15 & 20 & 6 & 9 & 50 \\
\hline Thysanoptera & 0 & 46 & 2 & 0 & 48 \\
\hline Panorpidae & 13 & 8 & 13 & 13 & 47 \\
\hline Rhagionidae & 18 & 5 & 14 & 5 & 42 \\
\hline Limacodidae & 11 & 8 & 8 & 15 & 42 \\
\hline Saturniidae & 0 & 0 & 31 & 10 & 41 \\
\hline Muscidae & 18 & 12 & 7 & 1 & 38 \\
\hline Anobiidae & 5 & 10 & 19 & 2 & 36 \\
\hline Phoridae & 5 & 13 & 15 & 1 & 34 \\
\hline Pamphiliidae & 20 & 14 & 0 & 0 & 34 \\
\hline Pergidae & 8 & 15 & 0 & 10 & 32 \\
\hline Psychodidae & 12 & 7 & 5 & 8 & 31 \\
\hline Dolichopodidae & 5 & 13 & 9 & 0 & 27 \\
\hline Mycetophagidae & 0 & 8 & 11 & 5 & 25 \\
\hline Lycaenidae & 0 & 1 & 0 & 24 & $\begin{array}{c}25 \\
\text { inued }\end{array}$ \\
\hline
\end{tabular}




\begin{tabular}{|c|c|c|c|c|c|}
\hline \multirow[b]{2}{*}{ Family } & \multicolumn{5}{|c|}{ Tree Species Groups } \\
\hline & $\begin{array}{l}\text { Black } \\
\text { Birch }\end{array}$ & $\begin{array}{c}\text { Black } \\
\text { Cherry }\end{array}$ & $\begin{array}{l}\text { Mixed } \\
\text { Maple }\end{array}$ & $\begin{array}{c}\text { Mixed } \\
\text { Oak }\end{array}$ & Total \\
\hline Oedemeridae & 10 & 9 & 2 & 3 & 24 \\
\hline Chloroperlidae & 3 & 0 & 16 & 6 & 24 \\
\hline Cimbicidae & 5 & 15 & 1 & 1 & 23 \\
\hline Diprionidae & 5 & 15 & 1 & 1 & 23 \\
\hline Thyatiridae & 2 & 0 & 20 & 1 & 23 \\
\hline Cryptophagidae & 0 & 10 & 9 & 2 & 20 \\
\hline Scatopsidae & 13 & 3 & 0 & 4 & 20 \\
\hline Peltoperlidae & 5 & 8 & 6 & 1 & 20 \\
\hline Drepanidae & 19 & 0 & 1 & 0 & 20 \\
\hline Stratiomyidae & 2 & 5 & 7 & 4 & 19 \\
\hline Tettigoniidae & 8 & 8 & 1 & 2 & 19 \\
\hline Halictidae & 6 & 9 & 3 & 0 & 18 \\
\hline Melandryidae & 8 & 6 & 1 & 2 & 17 \\
\hline Corylophidae & 0 & 17 & 0 & 0 & 17 \\
\hline Anthocoridae & 5 & 0 & 10 & 2 & 16 \\
\hline Gryllacrididae & 11 & 2 & 3 & 1 & 16 \\
\hline Lampyridae & 7 & 2 & 5 & 1 & 15 \\
\hline Chloropidae & 2 & 11 & 0 & 2 & 15 \\
\hline Acrididae & 6 & 1 & 0 & 8 & 15 \\
\hline Sciomyzidae & 5 & 2 & 7 & 0 & 14 \\
\hline Cixiidae & 1 & 3 & 4 & 5 & 14 \\
\hline Coreidae & 3 & 8 & 0 & 3 & 14 \\
\hline Perlodidae & 6 & 0 & 6 & 1 & 14 \\
\hline Otitidae & 4 & 3 & 4 & 2 & 13 \\
\hline Pisauridae & 7 & 2 & 3 & 1 & 13 \\
\hline Sphingidae & 2 & 7 & 0 & 4 & 13 \\
\hline Melyridae & 3 & 7 & 2 & 0 & 12 \\
\hline Piophilidae & 5 & 6 & 0 & 1 & 12 \\
\hline Tineidae & 2 & 1 & 5 & 3 & 12 \\
\hline Baetidae & 4 & 4 & 3 & 1 & 12 \\
\hline Bittacidae & 3 & 5 & 2 & 2 & 12 \\
\hline Alleculidae & 6 & 2 & 2 & 1 & 11 \\
\hline Lycidae & 5 & 3 & 2 & 1 & 11 \\
\hline Pedilidae & 6 & 2 & 2 & 1 & 11 \\
\hline Oribatidae & 0 & 6 & 5 & 0 & 11 \\
\hline Pyrochroidae & 3 & 4 & 2 & 2 & 10 \\
\hline Pipunculidae & 2 & 3 & 0 & 4 & 10 \\
\hline Agromyzidae & 10 & 0 & 0 & 0 & 10 \\
\hline Coleophoridae & 0 & 10 & 0 & 1 & 10 \\
\hline Scolytidae & 8 & 0 & 1 & 0 & 9 \\
\hline Sphecidae & 5 & 3 & 0 & 2 & 9 \\
\hline Gasteruptiidae & 4 & 0 & 0 & 5 & 9 \\
\hline Derbidae & 5 & 2 & 1 & 1 & 9 \\
\hline Anthicidae & 3 & 0 & 3 & 2 & 8 \\
\hline Achilidae & 0 & 0 & 8 & 0 & 8 \\
\hline
\end{tabular}




\begin{tabular}{|c|c|c|c|c|c|}
\hline \multirow[b]{2}{*}{ Family } & \multicolumn{5}{|c|}{ Tree Species Groups } \\
\hline & $\begin{array}{l}\text { Black } \\
\text { Birch }\end{array}$ & $\begin{array}{l}\text { Black } \\
\text { Cherry }\end{array}$ & $\begin{array}{l}\text { Mixed } \\
\text { Maple }\end{array}$ & $\begin{array}{c}\text { Mixed } \\
\text { Oak }\end{array}$ & Total \\
\hline Alydidae & 2 & 2 & 2 & 1 & 8 \\
\hline Heptageniidae & 1 & 6 & 0 & 0 & 8 \\
\hline Cleridae & 2 & 2 & 1 & 1 & 7 \\
\hline Tephritidae & 1 & 2 & 3 & 1 & 7 \\
\hline Xylophagidae & 7 & 0 & 0 & 0 & 7 \\
\hline Buprestidae & 1 & 0 & 3 & 2 & 6 \\
\hline Helodidae & 0 & 2 & 4 & 0 & 6 \\
\hline Histeridae & 6 & 0 & 0 & 0 & 6 \\
\hline Lagriidae & 3 & 1 & 0 & 2 & 6 \\
\hline Ptilodactylidae & 2 & 2 & 0 & 1 & 6 \\
\hline Tachinidae & 3 & 0 & 0 & 3 & 6 \\
\hline Lonchaeidae & 0 & 6 & 0 & 0 & 6 \\
\hline Culicidae & 4 & 2 & 0 & 0 & 6 \\
\hline Xylomyidae & 4 & 0 & 0 & 2 & 6 \\
\hline Anthophoridae & 0 & 0 & 0 & 6 & 6 \\
\hline Berytidae & 4 & 2 & 0 & 0 & 6 \\
\hline Uloboridae & 0 & 6 & 0 & 0 & 6 \\
\hline Papilionidae & 0 & 6 & 0 & 0 & 6 \\
\hline Cucujidae & 2 & 3 & 0 & 0 & 5 \\
\hline Byrrhidae & 0 & 2 & 0 & 3 & 5 \\
\hline Sphaeroceridae & 5 & 0 & 0 & 0 & 5 \\
\hline Acroceridae & 1 & 3 & 0 & 1 & 5 \\
\hline Hydropsychidae & 2 & 0 & 2 & 1 & 5 \\
\hline Oecophoridae & 0 & 2 & 2 & 1 & 5 \\
\hline Dascillidae & 0 & 2 & 2 & 0 & 4 \\
\hline Cephaloidae & 2 & 1 & 0 & 0 & 4 \\
\hline Lonchopteridae & 0 & 0 & 3 & 1 & 4 \\
\hline Phymatidae & 0 & 2 & 3 & 0 & 4 \\
\hline Philopotamidae & 0 & 2 & 0 & 2 & 4 \\
\hline Eriocraniidae & 0 & 4 & 0 & 0 & 4 \\
\hline Bostrichidae & 0 & 2 & 1 & 1 & 3 \\
\hline Bombyliidae & 0 & 0 & 1 & 2 & 3 \\
\hline Cephidae & 0 & 0 & 0 & 3 & 3 \\
\hline Delphacidae & 0 & 1 & 2 & 0 & 3 \\
\hline Flatidae & 0 & 2 & 0 & 1 & 3 \\
\hline Brachycentridae & 0 & 3 & 0 & 0 & 3 \\
\hline Isotomidae & 0 & 3 & 0 & 0 & 3 \\
\hline Lycosidae & 0 & 0 & 3 & 0 & 3 \\
\hline Silphidae & 2 & 0 & 0 & 0 & 2 \\
\hline Artematopidae & 0 & 2 & 0 & 0 & 2 \\
\hline Ephydridae & 0 & 2 & 0 & 0 & 2 \\
\hline Chrysididae & 2 & 0 & 0 & 0 & 2 \\
\hline Limnephilidae & 0 & 0 & 2 & 0 & 2 \\
\hline Rhyacophilidae & 0 & 0 & 0 & 2 & 2 \\
\hline Siphlonuridae & 2 & 0 & 0 & 0 & 2 \\
\hline
\end{tabular}




\begin{tabular}{|c|c|c|c|c|c|}
\hline \multirow[b]{2}{*}{ Family } & \multicolumn{5}{|c|}{ Tree Species Groups } \\
\hline & $\begin{array}{l}\text { Black } \\
\text { Birch }\end{array}$ & $\begin{array}{c}\text { Black } \\
\text { Cherry }\end{array}$ & $\begin{array}{l}\text { Mixed } \\
\text { Maple }\end{array}$ & $\begin{array}{c}\text { Mixed } \\
\text { Oak }\end{array}$ & Total \\
\hline Baetiscidae & 0 & 0 & 2 & 0 & 2 \\
\hline Diplopoda & 0 & 0 & 1 & 1 & 2 \\
\hline Nymphalidae & 0 & 1 & 0 & 1 & 2 \\
\hline Coleoptera & 0 & 0 & 0 & 1 & 1 \\
\hline Erotylidae & 0 & 0 & 0 & 1 & 1 \\
\hline Lucanidae & 0 & 0 & 0 & 1 & 1 \\
\hline Rhipiceridae & 0 & 0 & 0 & 1 & 1 \\
\hline Endomychidae & 0 & 0 & 1 & 0 & 1 \\
\hline Salpingidae & 0 & 0 & 0 & 1 & 1 \\
\hline Calliphoridae & 0 & 0 & 0 & 1 & 1 \\
\hline Anisopodidae & 1 & 0 & 0 & 0 & 1 \\
\hline Anthomyzidae & 0 & 0 & 1 & 0 & 1 \\
\hline Camillidae & 1 & 0 & 0 & 0 & 1 \\
\hline Curtonotidae & 0 & 0 & 0 & 1 & 1 \\
\hline Athericidae & 0 & 0 & 1 & 0 & 1 \\
\hline Hymenoptera & 0 & 0 & 0 & 1 & 1 \\
\hline Colletidae & 0 & 1 & 0 & 0 & 1 \\
\hline Xyelidae & 0 & 1 & 0 & 0 & 1 \\
\hline Pelecinidae & 0 & 0 & 0 & 1 & 1 \\
\hline Andrenidae & 0 & 0 & 1 & 0 & 1 \\
\hline Homoptera & 1 & 0 & 0 & 0 & 1 \\
\hline Acanaloniidae & 0 & 0 & 1 & 0 & 1 \\
\hline Phryganeidae & 0 & 0 & 1 & 0 & 1 \\
\hline Hydroptilidae & 0 & 0 & 1 & 0 & 1 \\
\hline Amaurobiidae & 0 & 0 & 1 & 0 & 1 \\
\hline Oxyopidae & 0 & 0 & 1 & 0 & 1 \\
\hline Plutellidae & 0 & 0 & 1 & 0 & 1 \\
\hline Tischeriidae & 0 & 0 & 0 & 1 & 1 \\
\hline Ephemerellidae & 0 & 0 & 0 & 1 & 1 \\
\hline Perlidae & 0 & 0 & 0 & 1 & 1 \\
\hline Chilopoda & 0 & 1 & 0 & 0 & 1 \\
\hline TOTALS & 51771 & 25690 & 22420 & 15670 & 115551 \\
\hline
\end{tabular}




\section{Blank Page in Original Bulletin}




\section{Blank Page in Original Bulletin}




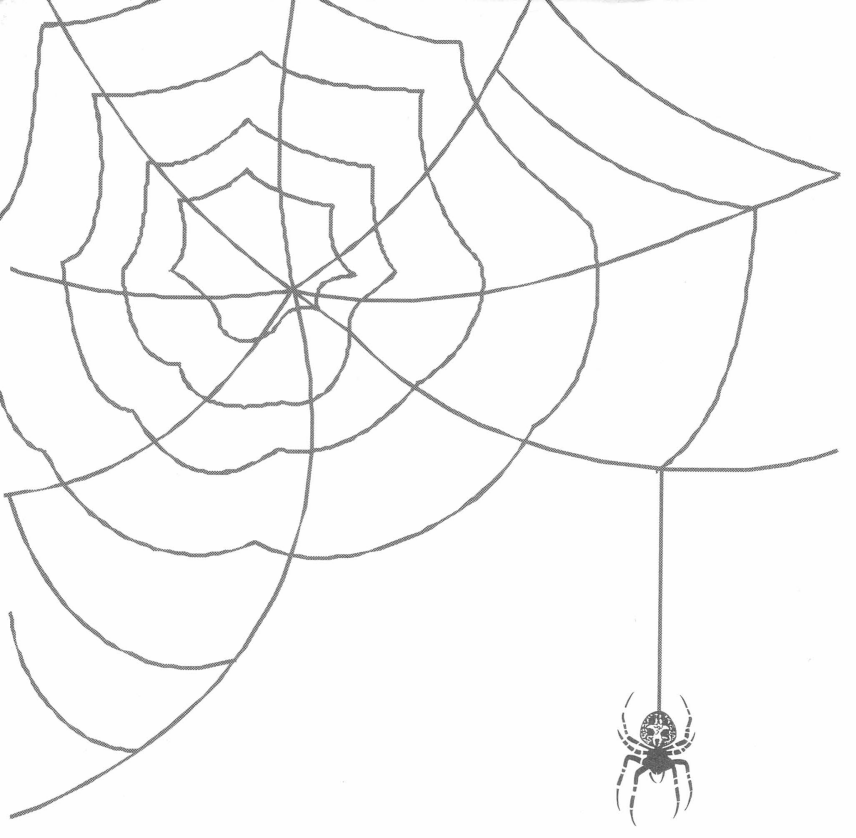

Agricultural and Forestry

Experiment Station

Non-Profit Organization

U.S. Postage PAID

West Virginia University

PO Box 6108

Morgantown, WV 26506-6108

Morgantown, WV

Permit No. 34

SERIALS DEPARTMENT

EVANSDALE LIBRARY

WEST VIRGINIA UNIVERSITY

PO BOX 6105

MORGANTOWN WV 26506-6105 